\title{
CAMINHOS DA REDEMOCRATIZAÇÃO: ALGUNS APONTAMENTOS DA POLÍTICA NO PÓS-GUERRA EM PERNAMBUCO (1945-1946)
}

\section{THE WAYS OF REDEMOCRATIZATION: SOME POLICY NOTES AFTER THE WAR IN PERNAMBUCO (1945-1946)}

\author{
Diego Carvalho da Silva ${ }^{524}$
}

Resumo: $O$ presente artigo tem por objetivo analisar o contexto sociopolítico durante os dois primeiros anos do pós-Estado Novo em Pernambuco. A análise será focada no processo da reorganização dos principais partidos políticos que adentraram nos debates políticos iniciado em princípios de 1945 a partir do encaminhamento do processo de abertura da política do Estado Novo. O intuito maior é apresentar com detalhes algumas das particularidades da política pernambucana, as quais podem nos fazer refletir melhor sobre a complexidade que se vivia durante o processo denominado pela historiografia recente como transição democrática, que não deve ser pensado como algo que ocorreu de forma homogênea em todo 0 país.

Palavras-chaves: Redemocratização; Pernambuco; Agremiações partidárias.

\begin{abstract}
This article aims to analyze the sociopolitical context during the first two years after Estado Novo in Pernambuco. The analysis will be focused on the process of reorganization of the major political parties stepped into the discussions political that started in early 1945s from the routing process of opening the new state's policy. The larger purpose is to analyze in detail some of the particularities of Pernambuco's policy, which can make us think better about the complexity that lived during the process called by the recent historiography as democratic transition, which should not be thought of as something that occurred homogeneously across the country.
\end{abstract}

Keywords: Estado Novo; Pernambuco; political parties.

\section{RUMO À TRANSIÇÃO DEMOCRÁTICA}

O ano de 1945 ficou marcado por uma série de transformações no cenário político mundial. Merece destaque a derrocada final do exército alemão e o fim da Segunda Guerra Mundial após o desfecho de vastador do lançamento das bombas nucleares no Japão. Em maio, encerram-se os conflitos na Europa e começou a ser encaminhada uma série de mudanças políticas sob o comando das potências aliadas, sob a

\footnotetext{
${ }^{524}$ Mestrando em história pela Universidade Federal Fluminense (UFF)
} 
liderança dos Estados Unidos e da União Soviética. Essas transformações ocorridas no outro lado do Atlântico refletiram diretamente no cenário político nacional que vivenciava o período do Estado Novo.

Com relação à política nacional, os fatos indicam que em princípios de 1945, mais exatamente, a partir de fevereiro deste ano, era possível identificar alguns indícios do encaminhamento do processo de abertura política. ${ }^{525}$ Em meio ao processo de abertura, o presidente Getúlio Vargas demonstrou mais uma vez suas habilidades políticas, ao encaminhar a transformação de seu perfil de ditador para o empreendedor da transição para democracia. Isso ficou evidente quando na convocação do interventor do estado de Pernambuco, Agamenon Magalhães, para assumir a Pasta da Justiça de onde passou encaminhar as mudanças necessárias para a abertura política. Em fins de maio de 1945, foi aprovado o Decreto $\mathrm{n}^{0} 7.586$, que popularmente ficou conhecida como a "Lei Agamenon" em homenagem ao próprio Ministro que coor denou sua elaboração. Através deste decreto estava criado o novo Código Eleitoral, no qual estavam conti das as regras da transição. Entre as suas determinações, apresentava-se uma data para realização de eleições para presidente da república para princípios de dezembro.

Ao mesmo tempo em que ocorriam estas transformações, foram realizadas nas principais cidades do país manifestações, por um lado, de apoio ao presidente Vargas e, por outro, de protestos contra a sua continuidade no poder. Os principais opositores de Vargas se agregaram em torno da União Democrática Nacional (UDN), crítica ferrenha da política trabalhista e de seu fundador Getúlio Vargas. Para os udenistas, o presidente era um ditador que se aproveitava da ignorância da população para dominá-las como simples marionetes, que fornecia "migalhas" em troca da devoção dos populares crédulos.

Por outro caminho seguiam as forças aliadas de Vargas, que viam na sua continuidade a possibilidade de preservação das conquistas obtidas e a esperança de outras que poderiam vir. Dentre os feitos de seus defensores, merece destaque o movimento queremista, que desde meados de abril de 1945, pas sou a agregar grupos e pessoas favoráveis à continuidade de Vargas como orientador da transição demo crática. Segundo o historiador Jorge Ferreira, "a atuação e a intervenção dos trabalhadores, determinados e com vontade política, impediram que a transição à democracia ficasse restrita a uma negociação, pactuada pelo alto, entre as elites" ${ }^{526}$ O movimento queremista chegou a ganhar a adesão dos comunistas, os quais passaram a ver o projeto de Vargas como a melhor via para o encaminhamento da transição para a

\footnotetext{
${ }^{525}$ Segundo Michelle Reis, durante todo o ano de 45 não existia mais ditadura do estado novo, a imprensa estava livre da censura, os partidos estavam se organizando, a campanha da oposição tomava as ruas e propaganda estatal suspensa. Ver MACEDO, Michelle. O movimento queremista e a democratização de 1945: Trabalhadores na luta por direitos. Rio de Janeiro: 7Letras, 2013, p. 11.

${ }^{526}$ FERREIRA, Jorge. O Imaginário Trabalhista: getulismo, PTB e cultura política popular 1945 - 1964. Rio de Janeiro: Civilização Brasileira, 2005, p. 25.
} 
democracia e também defenderam a instalação da constituinte com Getúlio no comando. Por fim, merece destaque o papel exercido pelo Partido Trabalhista Brasileiro (PTB), o qual tinha suas raízes no projeto po lítico varguista e passou a ser o abrigo para os seus defensores.

No decorrer do ano, Vargas e seus ministros tomaram outras medidas que terminaram por aumentar a insatisfação de seus opositores, como ocorreu após a aprovação da "Lei Antitruste", que visava entre outras medidas, defender os interesses nacionais, assim como combater as práticas antieconômicas, como no caso dos trustes. Na segunda metade de 1945, foram sendo definidos também quais seriam os candidatos à sucessão de Vargas para as eleições de dezembro. A UDN indicou o Brigadeiro Eduardo Gomes, um militar prestigiado em seu meio, porém com pouca popularidade. Já o Partido Social Democrático (PSD), o General Eurico Gaspar Dutra, que havia sido Ministro da Guerra durante boa parte do governo de Vargas. É interessante notar o fato da indicação de dois militares de alta patente para a sucessão presidencial. Os demais partidos que se organizaram no período buscaram se articular com os partidos majori tários ou terminaram por lançar candidatos próprios como foi o caso do Partido Comunista que indicou 0 engenheiro ledo Fiúza.

Ao se aproximarem as eleições, Vargas ainda tentou fazer algumas alterações na Lei Eleitoral, fato que gerou novos embates e culminou com a sua deposição da presidência antes mesmo das eleições de dezembro. O estopim da intervenção militar que o depôs foi a nomeação de Benjamin Vargas, irmão do Presidente, em 28 de outubro, para o cargo de Chefe de Polícia do Distrito Federal no lugar de João Alber to Lins de Barros. Com seu irmão neste cargo, as manifestações queremistas poderiam ganhar novo fôlego na Capital Federal. No entanto, Benjamin não teria vida longa na função. No dia seguinte, os chefes militares, entre eles os generais Eurico Gaspar Dutra e Góes Monteiro, desferiram o golpe final contra Vargas, que foi deposto da presidência e partiu em direção às terras do Sul sem demonstrar quaisquer sinais de re sistência.

Assumiu o executivo nacional o Presidente do Supremo Tribunal Federal, José Linhares. Uma de suas primeiras medidas foi determinar a revogação do Decreto $n^{0} 8.063$, o que significava o retorno das determinações do Código Eleitoral, no que referia à realização das eleições estaduais, que foram remarcadas para o dia 6 de maio de 1946. Linhares também revogou da "Lei Malaia" em 9 de novembro de 1945, medida que seriam aplaudida de pé pelos principais opositores de Vargas. Além disso, o novo presidente encaminhou um processo de "limpeza" contra os aliados da política varguista, que foram em boa parte substituídos nas diversas unidades federativas, sem contar com a perseguição aos petebistas que sofre ram consideráveis restrições em suas campanhas de protesto contra a nova gestão. 
Por sua vez, Vargas, isolado em São Borja, manteve-se, por alguns dias, isolado do jogo político que se instaurou após a sua queda. Ao mesmo tempo as pesquisas indicavam a vitória do brigadeiro Edu ardo Gomes com larga vantagem de votos à frente de Dutra. Os petebistas temiam a vitória da UDN, que sinalizou também a possibilidade da destruição de todo o legado de Vargas. No entanto, o líder trabalhista, no apagar dos refletores optou pelo apoio ao PSD, tendo esta notícia sido anunciada no último discurso de Dutra, realizado cinco dias antes das eleições presidenciais. Em troca ficou acordado que caso o PSD se sagrasse vencedor, seriam asseguradas as conquistas com as leis trabalhistas, além de outras recompensas políticas para o PTB.

Em 2 de dezembro de 1945 foram realizadas as eleições no Brasil. Segundo os dados gerais do pleito presidencial foram apurados no total 5.870.667 votos. Ao final da contagem dos votos, apontou-se um resultado que surpreenderia a todos, tendo em vista que houve uma virada inesperada de Dutra, o qual vencera o pleito, recebendo 52,39\% dos votos contra 34,74\% conquistados por Eduardo Gomes. A aliança PSD-PTB tinha sido vitoriosa com uma vantagem considerável sobre o seu principal oponente, causando a decepção dos udenistas que tinham plena certeza da vitória do brigadeiro.

Com relação aos números gerais do pleito de dezembro para os cargos de senador e deputados para a assembleia constituinte pode-se afirmar que o PSD se sobressaiu sobre os outros partidos, sendo majoritário na distribuição das cadeiras para ambos os cargos. As lideranças pessedistas eram - em sua maioria - figuras que tinham sido beneficiadas durante o Estado Novo. Hélio Silva afirma que os resultados eleitorais de 1945 serviram para mostrar que o golpe de 29 de outubro não afetara as bases do situacionismo estadonovista (SILVA, 1976, p. 324), argumento aceitável, tendo em vista o sucesso da antiga máquina pessedista a nível nacional e local. Sendo assim, a transição para a democracia passou a ser coordenada pelo PSD, que é visto por Lúcia Hippolito como um "partido de centro", fiador da estabilidade política durante o período democrático que se estendeu até fins de março de $1964 .{ }^{527}$

As eleições de dezembro consolidaram o fim do Estado Novo, abrindo as discussões para a elabo ração de uma nova constituição do Brasil. Logo no início de 1946 ocorreu a cerimônia de posse do Presi dente Dutra que tinha a missão de dar continuidade ao processo de transição democrática. Finalmente, em 18 de setembro de 1946, foi promulgada a nova constituição de República. Depois de concluídos os traba Ihos na constituinte, a Assembleia transformou-se no Congresso Nacional, dividindo-se em Senado Federal e Câmara dos Deputados, sendo estabelecida a data da realização das eleições estaduais para 19 de ja-

\footnotetext{
${ }^{527}$ HIPOLLITO, Lúcia. De raposas e reformistas: O PSD e a experiência democrática brasileira, 1945-64. Rio de Janeiro: Paz e Terra, 1985, p. 253.
} 
neiro de 1947. Estavam encerrados os debates em torno da transição democrática nacional, restava agora às unidades federativas e aos municípios darem continuidade a este processo.

\section{OS PARTIDOS E A POLÍTICA NACIONAL NO PÓS-ESTADO NOVO}

Em fins de novembro de 1945, quando ocorreu a deposição de Vargas, boa parte dos partidos políticos já havia se organizado de acordo com as exigências do Código Eleitoral elaborado ainda durante 0 Estado Novo. O cenário político, ao menos oficialmente, estava renovado e os partidos que desejassem participar dos pleitos, tiveram que se enquadrar nos preceitos estabelecidos. É possível afirmar que existiam mecanismos acima de tudo democráticos, porém com regras a serem respeitadas, para que assim fos se assegurada a sua continuidade.

Sendo assim, o ano de 1946 seria marcado pela continuidade do processo de transição. Com mais de duas dezenas de partidos registrados, o cenário político nacional entrou numa nova fase, que para mui tos historiadores é tida com uma das mais democráticas da nossa história. ${ }^{528}$ Destacaram-se entre as diversas agremiações registradas o Partido Social Democrático, a União Democrática Nacional e o Partido Tra balhista Brasileiro. Merece ênfase particular o Partido Comunista do Brasil (PCB), visto que os comunistas exerceram uma influência marcante durante os dois primeiros anos da experiência democrática, quando puderam desfrutar um breve período na legalidade, até o momento em que foi determinada cassação de seu registro pelos juízes do TSE em maio de 1947.

\section{PESSEDISTAS E UDENISTAS EM DISPUTA PELA HEGEMONIA EM PERNAMBUCO}

Em meio ao processo da redemocratização foi fundado o Partido Social Democrático. Criado no Rio de Janeiro em 17 de julho de 1945, estando entre seus diretores e fundadores nomes de antigos aliados de Vargas como Benedito Valadares, Agamenon Magalhães e Ernani do Amaral Peixoto. Apesar da existência de um diretório nacional com sede na capital, o partido tinha um traço marcante, que era seu perfil descentralizador em suas seções estaduais, que estariam praticamente livres para compor alianças e indicar candidatos de acordo com seus interesses locais. O pessedista paraibano José Jóffily Bezerra de Melo disse em uma oportunidade, "Bom pessedista é, antes de tudo, aquele que tem votos", ${ }^{52}$ uma frase

${ }^{528}$ DELGADO, Lucilia de Almeida Neves. "Partidos políticos e frentes parlamentares: projetos, desafios e conflitos na democracia". In: DELGADO, Lucilia de Almeida Neves; Ferreira, Jorge (Org.). O Brasil Republicano: O tempo da experiência democrática. Rio de Janeiro: Civilização Brasileira, 2003, v. 3, p. 151.

${ }^{529}$ HIPPOLITO, Op. cit., p. 44. 
que demonstra um dos princípios que guiava o partido. De fato, os pessedistas mostraram-se hábeis em diversos momentos de tensão durante boa parte do período democrático, assim como suas crises internas iriam provocar instabilidades que geralmente se refletiam no cenário político nacional.

Em Pernambuco, a estruturação do partido foi coordenada por figuras políticas marcantes durante a vigência do Estado Novo, como Etelvino Lins, Barbosa Lima Sobrinho e do seu presidente local, Agamenon Magalhães, era o responsável pelas articulações do diretório local com as lideranças nacionais. A seção pernambucana foi fundada em meados de 1945, agregando antigos membros da burocracia estadonovista, que assumiram a comissão executiva do partido, proprietários agrícolas de gêneros variados e regiões do estado. Além desses, contava ainda com um contingente considerável de funcionários públicos e de profissionais liberais.

É possível afirmar que o PSD - em particular sua seção pernambucana - foi muito pragmático em toda sua trajetória pelo período democrático. Isolava-se em certas ocasiões, em outras procurava aliados nas mais díspares legendas, assim como mudava de postura de acordo com o contexto vivido. Sendo assim, somos levados a compreender que a diretriz básica do partido em Pernambuco era acumular votos de cadeiras, comportamento esse que iria gerar conflitos internos entre as direções locais e nacionais. Portanto é preciso reforçar que em Pernambuco, na maioria das vezes, as decisões que prevaleceram foram tomadas localmente e nem sempre eram coerentes com os ditames do diretório nacional. Esta prática era na verdade uma das grandes armas das quais se serviram as lideranças pessedistas. Boa parte do êxito eleitoral do PSD nacionalmente foi consequência deste caráter descentralizador que possibilitou a conservação de sua hegemonia política nacionalmente durante o período democrático.

Sob o lema da "eterna vigilância" foi fundada a União Democrática Nacional. Idealizada ainda em fins de 1943, quando foi publicado o Manifesto dos Mineiros, em que seus correligionários trataram de dirigir severas críticas à Vargas e também a exigir o início de um processo de abertura política. Entre os seus signatários estavam figuras como Artur Bernardes, Afonso Arinos, Virgilio de Mello Franco e Milton Cam pos. O partido foi fundado em 7 de abril de 1945, sendo nomeado como seu presidente o baiano, Octavio Mangabeira e como secretário geral Virgilio de Mello Franco. Entre seus diretores e fundadores, predominavam os profissionais liberais como jornalistas, advogados, médicos, professores, havendo ainda alguns industriais, militares e proprietários de terras. Assim como o PSD, sua composição era diversificada, tendo este partido agregado boa parte dos que haviam sido destronados no decorrer do governo de Vargas. Era quase que unânime no partido a aversão ao líder do Estado Novo, sendo esta a principal fonte agregadora dos membros da UDN, ou seja, o sentimento antigetulista e de combate à sua obra. Como projeto para na - 
ção, a UDN trazia como base de suas ideias o liberalismo clássico, era favorável à entrada do capital internacional no Brasil, acima de tudo antigetulista, anticomunista e defensora de princípios moralistas da políti ca. $^{530}$

Em Pernambuco, a UDN foi fundada dentro da mesma lógica do diretório nacional, ou seja, por oposicionistas e/ou dissidentes da política varguista com destaque para o ex-governador Carlos de Lima Cavalcanti, os ex-deputados João Cleofas e Alde Sampaio. É preciso enfatizar que além do antigetulismo a seção pernambucana carregava consigo também um sentimento de repulsa ao líder pessedista Agamenon Magalhães, podendo-se até dizer que em proporções maiores que ao Presidente Vargas. Apesar de muitos intentos, a UDN manteve-se como segunda força em Pernambuco durante o período democrático.

A composição da seção pernambucana era também heterogênea, agregando intelectuais, proprietários de indústrias, médicos, advogados, comerciantes, usineiros e proprietários agrícolas, que comungavam do sentimento de repulsa a Vargas e Agamenon, assim como também aos comunistas. A oposição aos correligionários do Estado Novo causou muitas vezes a cegueira nas lideranças locais, que abriam as suas portas para alguns dissidentes do PSD local e fazia deles figuras de destaque do partido, como ocorreu com os ex-pessedistas Novaes Filho e Neto Campelo em meados de 1946. Já nos primeiros pleitos realizados em Pernambuco após o Estado Novo, a UDN formou uma coalizão, a nível estadual, conhecida como Coligação Pernambucana, com o Partido Libertador (PL) e com o Partido Democrata Cristão (PDC), que permaneceu forte até os primeiros anos da década de 1950. Foi a forma encontrada pelos udenistas de reforçar a oposição contra a força majoritária do PSD dentro do estado.

Enfatizo que devido à complexidade do jogo eleitoral vigente em todo o estado é preciso que se evite a reprodução de ideias feitas por alguns autores ${ }^{531}$, que buscam enquadrar as composições tanto do PSD quanto da UDN em perfis generalistas que nem sempre condizem com o real cenário político local. Portanto, pode-se afirmar que pouca coisa, de fato, diferenciava udenistas e pessedistas em Pernambuco no que tange ao critério composição de quadros, prevalecendo acima de tudo as divergências nos projetos políticos e nas intrigas históricas entre as suas lideranças locais.

\footnotetext{
${ }^{530}$ BENEVIDES, Maria Victoria Mesquita. A União Democrática Nacional: um partido em questão. São Paulo: Cadernos Cedec, 1978. v. 1, p. 280.

${ }^{531}$ Ver BENEVIDES, Op. cit., p. 235. Ver também LAVAREDA, José Antônio. Partidos no pós-guerra: primeiras eleições em Pernambuco, 1945-1947. Recife: Ed. Universitária da UFPE, 2008, p. 48.
} 


\section{O PCB E O “PERIGO VERMELHO" EM PERNAMBUCO}

Em princípios de abril de 1945, Vargas concedeu a anistia aos presos políticos do Estado Novo sendo este o ponto de partida de uma nova fase que os comunistas conheceriam, a da legalidade. Na lide rança do partido estava Luis Carlos Prestes, auxiliado por Diógenes Arruda, Maurício Grabois, João Amazonas. Destes, apenas o último tinha origem operária, algo que demonstra a nova ordem do dia dentro do partido. Segundo Jorge Ferreira, “O PCB, sobretudo a partir de 1945, oscilou entre a política do 'partido de quadros', restringindo-se à participação aos revolucionários profissionais, e do 'partido de massas', abrindo-se para a sociedade". ${ }^{532}$ Nos anos 1940, o PCB ressurgiu com um discurso aberto de apoio à democracia-liberal, porém internamente era um partido marcado pela forte influência do stalinismo ${ }^{533}$ que deu contornos ao prestismo nacionalmente.

No decorrer de 1945, os comunistas intensificaram suas atividades com o intuito de organizar seus diretórios, comitês e células por todo o Brasil, conseguindo atrair militantes e simpatizantes de forma surpreendente, inclusive no meio intelectual. Com a aprovação do registro de sua legenda, os comunistas poderiam atuar abertamente e desfrutar de liberdade que até antes desconheciam. Concomitantemente, foi intensificada a campanha de combate ao avanço dos comunistas que continuaram a ser vigiados pela polícia política e perseguidos pelo olhar vigilante dos anticomunistas.

Em Pernambuco, o PCB foi reestruturado com êxito ainda no ano de 1945, mesmo que pesando 0 fato do estado ter sido uma das regiões onde a repressão mais atuou durante a vigência do Estado Novo. O Comitê Estadual do partido foi empossado em ato público realizado em maio de 1945 no Parque 13 de Maio, localizado numa área central do Recife, tendo na sua direção os comerciários Alfredo Richmond e Carlos Cavalcanti, os operários João Justino e Antônio Marques e o ex-militar Gregório Bezerra. Além desses, veio em meados de 1945, para reforçar o quadro do estado, Diógenes Arruda Câmara que tinha como missão consolidar as bases do partido na região. A vinda do secretário de organização do Comitê Nacional nos leva a pensar que Pernambuco seria um ponto chave nos planos da direção nacional do partido.

A composição do partido era heterogênea e sua base de militantes se concentrava na capital, Recife, e nos municípios vizinhos como no caso de Jaboatão, Paulista e Olinda, onde estava localizada grande parte das indústrias do estado. Integravam O PCB local: profissionais liberais como médicos,

532 FERREIRA, Jorge. Prisioneiros do mito: Cultura e imaginário político dos comunistas no Brasil (1930-1956). Rio de Janeiro/Niterói: Mauad/Eduff, 2002. v. 1, p. 43.

533 "No Brasil, o culto a Stálin iniciou-se mais tarde, particularmente após a II Guerra. As exaltações ao líder bolchevista na imprensa comunista brasileira repetiam a propaganda extravagante e pouco elaborada dos soviéticos" FERREIRA, Op. cit., $p$. 221. 
advogados, comerciários e jornalistas, assim como estavam presentes também operários, estudantes de diversos cursos e funcionários públicos. Durante o período em que esteve na legalidade, o PCB era tido como a terceira força em Pernambuco, porém é preciso enfatizar um detalhe, todo esse sucesso concentrava-se no Recife e nas cidades vizinhas, onde os comunistas concentravam boa parte de sua militância.

Desta forma, é possível verificar o cenário particular da política pernambucana, que entre outros pontos de divergências fugia a regra da tríade hegemônica nacional PSD-UDN-PTB durante a vigência do período democrático. Os comunistas, concentrados nas áreas urbanas do estado, iriam representar uma grande força, mesmo após ser decretada a cassação do registro do PCB em maio de 1947, quando passaram a usufruir de sua popularidade na região para manterem-se, na medida do possível, ativos politicamente, ainda que na clandestinidade. De fato, a capital pernambucana era uma região de forte militância do PCB, algo que terminara por provocar uma forte atuação da polícia política e das forças armadas com 0 intuito de combater o "perigo vermelho" que sempre que necessário era trazido à tona tendo em vista a intensificação da vigilância contra o avanço dos comunistas.

\section{O PTB E OS OUTROS PARTIDOS EM PERNAMBUCO}

Inspirado no tradicional Labour Party inglês, o PTB foi fundado segundo os registros legais em 26 de março de $1945,{ }^{534}$ tendo como idealizadores aliados históricos de Getúlio Vargas, como 0 Ministro do Trabalho, Alexandre Marcondes Filho, o diretor do Departamento Nacional do Trabalho (DNT), José Segadas Viana e Agamenon Magalhães, então Ministro da Justiça. Segundo Maria Celina D’Araújo, "0 PTB foi de fato uma invenção da burocracia ministerial e sindical vinculada ao Estado Novo, mas só se viabilizou porque houve uma massa disponível para aderir à proposta". ${ }^{535}$

Ao mesmo tempo em que o PTB era organizado, foi articulada a campanha queremista, por sindicalistas que desejavam a continuidade de Vargas que receberam apoio "discreto" dos petebistas, visto que o partido não podia, nem queria fugir das regras do jogo eleitoral, para assim evitar possíveis ataques por parte dos que faziam oposição ao líder do Estado Novo. Os trabalhistas deveriam, assim, ser uma alternativa para os trabalhadores que após o fim do Estado Novo desejavam a preservação de seus direitos, ao mesmo tempo em que os seus fundadores desejavam mantê-los afastados do Partido

\footnotetext{
534 D'ARAUJO, Maria Celina. Sindicatos, carismas e poder. O PTB de 1945-65. Rio de Janeiro: Editora FGV, 1996, p. 27.

${ }^{535}$ D’ARAUJO, Op. cit., p. 26.
} 
Comunista, que crescia consideravelmente a partir de sua reorganização em meados de 1945. Logo depois de fundado, os seus cargos diretivos ficaram nas mãos de sindicalistas como Baeta Neves, Luis Augusto França e Antonio Francisco Carvalhal, que com o tempo seriam afastados da dianteira do partido.

Em Pernambuco, a seção do PTB não teve força suficiente para mobilizar parte considerável dos sindicalistas, espaço que já era ocupado pelos comunistas. Em todo estado, o partido teve participação discreta durante boa parte do período democrático, obtendo rendimentos insignificantes nos pleitos realizados. Seu insucesso pode ser compreendido também pelo fato do eleitorado do PTB ser tradicionalmente urbano, desta forma em um estado como Pernambuco, onde grande parte da população vivia nas áreas rurais, seria muito difícil para os trabalhistas obter popularidade e êxitos eleitorais.

Em meio ao processo de formação dos partidos políticos em 1945, foi organizado o Partido Demo crata Cristão (PDC), de forte militância de católicos e anticomunistas. Suas bases política assentavam-se nas ideias da Democracia Cristã e aspirava ser uma terceira via política nacionalmente. ${ }^{536} \mathrm{O}$ partido absorveu os membros do inexpressivo Partido Popular (PP) e do Partido Republicano Democrático (PRD). Seu primeiro presidente foi o professor da Faculdade de Direito da Universidade de São Paulo, Antônio Ferreira Cesarino Júnior, sendo a sua composição heterogênea, agregando em sua direção nacional professores, advogados e estudantes paulistas. No geral, era um partido moralista e, acima de tudo, católico. Sandro Anselmo Coelho argumenta que o pensamento predominante do partido em sua fase inicial era marcado pela defesa do liberalismo econômico, do anticomunismo e de uma democracia controlada e disciplina da. ${ }^{537}$ Em Pernambuco, o Padre Arruda Câmara era quem estava à frente da seção local, tendo o partido na região gravitado em torno da UDN, com a qual compôs a conhecida Coligação Pernambucana ${ }^{538}$ nos primeiros anos do período democrático.

Já o Partido Republicano (PR), fundado pelo ex-presidente da República Arthur Bernardes, que fora também um dos articuladores da UDN, assim como um crítico ativo do governo varguista. Com com posição heterogênea, o partido integrava profissionais liberais, militares e figuras políticas que tinham per dido espaço após a Revolução de 1930. Em Pernambuco era liderado por Eurico de Souza Leão, agregando na sua direção figuras como professores, militares, jornalistas e advogados. Durante o período demo crático, não conseguiu agregar grande número de militantes, logo seus membros enfrentavam grandes dificuldades para agregar votos para sua legenda.

\footnotetext{
${ }^{536}$ COELHO, Sandro Anselmo. O Partido Democrata Cristão: teores programáticos da terceira via brasileira (1945-1964). In: Revista Brasileira de História. São Paulo, v.23, nº 46, 2003, p. 202.

${ }^{537}$ COELHO, Op. cit., p. 219.

${ }^{538}$ Um terceiro partido integrava a coligação em Pernambuco. Com pouca força no estado o Partido Libertador $(\mathrm{PL})$ presidido nacionalmente por Raul Pilla e com sede no Rio Grande do Sul decide juntar sua modesta força local com os udenistas.
} 
Com a redemocratização, o Partido de Representação Popular (PRP) retomou suas atividades, apresentando praticamente a mesma proposta de outrora, sendo atualizado apenas em alguns aspectos. Teve como primeiro presidente o Comandante Fernando Cochrane, que havia liderado o fracassado atentado contra Getúlio Vargas em maio 1938 e por isso foi reformado compulsoriamente e processado. ${ }^{539} \mathrm{O}$ partido era marcado pela presença de antigos membros ou simpatizantes da Ação Integralista Brasileira (AIB), tendo inclusive seu líder, Plínio Salgado, sido um de seus idealizadores e eleito como presidente do partido em fins de 1946.

Na sua trajetória durante o período democrático, os perrepistas, assim como seus antecessores, carregavam consigo e defendiam tenazmente o lema "Deus, pátria e família", como estava explícito em seu estatuto e nos discursos de suas principais lideranças. Porém é preciso enfatizar que após o fim do Estado Novo, os seus membros iriam aderir ao projeto democrático e para isso deveriam reformular seu discurso político e seus planos de ação, com o intuito de encobrir seus antigos laços e afinidades com o fascismo.

Com presença inexpressiva no norte e nordeste do país, sua militância concentrava-se razoavelmente no sudeste e fortemente no sul. Em Pernambuco, o PRP não conseguiu lograr grandes êxitos eleito rais e sua organização local ficou por conta de antigos membros da seção da AIB pernambucana e alguns novos simpatizantes de seu projeto político.

Por fim, destaco o Partido Republicano Democrático (PRD), que teve aprovado seu registro provisório em fins de julho de 1945, com sede no Rio de Janeiro. Pouco tempo depois mudaria sua denominação para Partido Republicano Trabalhista (PRT), permanecendo ativo até ser extinto depois de ser decreta do 0 Ato Institucional $n^{0} 2$, em fins de 1965. Sua direção era integrada predominantemente por profissionais liberais como advogados, professores, jornalistas e médicos. Segundo Antônio Lavareda o partido era

o exemplo maior da inexistência de base social própria. Um banco de legendas. Alternativa comum a todos os que têm pretensões eleitorais e não encontram a necessária receptividade nas demais máquinas partidárias. Um entre os 26 partidos que haviam obtido registro provisório no Tribunal Superior Eleitoral e conseguiram, às vésperas do pleito, apresentar a relação de 10.000 eleitores, ficando aptos a dele participar. ${ }^{540}$

Em Pernambuco, o PRD não teve muito sucesso nos pleitos que disputou sozinho, sendo suas conquistas insignificantes e quando elas ocorriam eram muito em decorrência da formação de alianças

\footnotetext{
${ }^{539}$ CALIL, Gilberto Grassi. O integralismo no pós-guerra: a formação do PRP, 1945-1950. Porto Alegre: EDIPURS, 2001, p. 144.

${ }^{540}$ LAVAREDA, Op. cit., p. 53.
} 
com partidos majoritários. Desta forma, o argumento construído por Lavareda tem fundamento e pode ser comprovado com uma simples análise dos resultados eleitorais durante a experiência democrática.

Tendo em vista todo este cenário pluripartidário da política nacional, é possível perceber quão grande é a sua complexidade a partir de uma simples explanação sobre os diversos projetos que eram de fendidos para a nação por cada agremiação partidária. Esse quadro geral aqui exposto serve como evidên cia da riqueza e da importância do estudo da política nacional deste período.

\section{PERNAMBUCO NO PÓS-ESTADO NOVO}

Na virada para a década de 1940, de um total de 2.688.240 habitantes que possuía Pernambuco, 1.900.432, ou seja, 70\% do total viviam em áreas rurais. Agamenon Magalhães, como Interventor do estado, sabia muito bem dessa realidade, até mesmo pelo fato de ser oriundo do município de Serra Talhada, localizado no Sertão pernambucano.

Durante sua gestão, Agamenon, tratou de reformar o ambiente urbano, tendo destaque a criação da Liga Social Contra o Mocambo que buscou desenvolver um projeto de reurbanização a partir da retirada dos mocambos e com a construção de moradias populares para acolher seus habitantes. A medida fazia parte de um projeto maior de seu governo para harmonizar as relações entre as classes que dividiam 0 meio urbano. Ao mesmo tempo tratou de efetuar projetos com intuito de recuperar o meio rural, tendo em vista provocar uma redução considerável do êxodo rural, que nesse período havia se intensificado. Para Dulce Pandolfi, sua política agrícola tinha as seguintes metas: "defesa da policultura e crítica à monocultura canavieira, ruralismo e fixação do homem à terra, ressurreição do Sertão, crítica às industrias artificiais, implantação de um sistema de cooperativa agrícola e combate ao latifúndio improdutivo". ${ }^{541}$ Após o final de Estado Novo, o Sertão pernambucano seria justamente onde o partido de Agamenon, o PSD, iria concentrar boa parte de seus votos e consequentemente manter sua hegemonia em Pernambuco durante boa parte do período democrático.

Durante a Segunda Guerra Mundial, Pernambuco foi uma região de importância chave após a adesão do Brasil ao lado dos aliados. A capital, Recife, recebeu um contingente considerável de soldados norte-americanos após acordos feitos com Getúlio Vargas, fundariam uma base para envio de soldados para o conflito na Europa. A base foi instalada no bairro do Ibura, região localizada na zona sul do Recife e que na época ainda era pouco povoada.

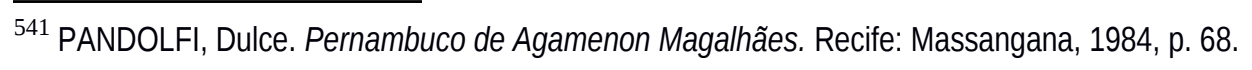


A região industrializada do Recife e das cidades vizinhas, de acordo com 0 senso de 1940, concentravam aproximadamente 600 mil habitantes de um total de três milhões que viviam em Pernambuco. Essa área era um grande centro comercial do Nordeste e suas linhas férreas tinham conexões que levavam a todos os estados da Região, que eram controladas pela empresa inglesa Great Western. A Pernambuco Tramways, outra empresa estrangeira, era a responsável pelo transporte urbano e pelo fornecimento de energia nos centros urbanos. Nessa época, o setor têxtil concentrava mais de 25 mil operários que se dividiam entre as 14 empresas que estavam situadas no Recife e nas cidades próximas. Com a redemocratização, os comunistas passariam a ganhar espaço entre os operários e fariam da região um reduto de apoio do PCB durante o período em que esteve legalizado. Segundo Antonio Lavareda, em fins de 1946, o PCB já somava pouco mais de 180 mil militantes, sendo que deste total, 25 mil estavam registrados na seção pernambucana do partido. ${ }^{542}$

Em princípios de 1945, quando Agamenon Magalhães foi convocado por Vargas para assumir a Pasta da Justiça, iria pronunciar a celebre frase "O regime vai mudar. E eu também". ${ }^{543}$ O pernambucano seria um dos responsáveis pelo encaminhamento do processo de transição, buscando minimizar os prejuízos que poderiam vir com a mudança de orientação do governo Vargas ou até mesmo uma possível queda. Assumiu como Interventor do estado, Etelvino Lins, então aliado de Agamenon e que atuara ao seu lado durante a vigência do Estado Novo. Além de governar o estado, Lins deveria cumprir a missão de organizar o PSD em Pernambuco, buscando assim reunir em torno da sigla as bases de apoio consolidadas por Agamenon em seu governo. Entre fevereiro, quando assumiu a interventoria, até fins de outubro de 1945, Lins passou a ser alvo de críticas por parte da oposição que nesse tempo ganhou força, que foi impulsionada após a fundação de uma seção da UDN dentro do estado.

Em meio aos protestos impulsionados pelos grupos opositores da política varguista, ocorreu em Pernambuco um episódio que marcaria a memória política local e contribuiria para o desgaste da imagem de Getúlio Vargas e de seus aliados políticos, quando em uma manifestação antigetulista no Recife foram atingidos mortalmente por tiros o estudante Demócrito de Souza Filho e o carvoeiro Manuel Elias dos Santos.

Após a queda de Vargas, Etelvino Lins foi substituído por ordem do presidente interino José Linhares pelo Presidente do Tribunal de Apelação, José Neves, que tratou de seguir o compromisso com a "neutralidade" do Governo Federal. Durante o período que esteve no governo, tratou de substituir os

\footnotetext{
542 LAVAREDA, Op. cit., p. 95.

${ }^{543}$ PANDOLFI, Op. cit., p. 85.
} 
interventores das prefeituras municipais por Juízes de direito com o intuito de afastar a as figuras ligadas ao Estado Novo.

Em janeiro de 1946, por determinação do presidente Dutra, o Interventor estadual foi substituído pelo procurador da Delegacia Fiscal, José Domingues da Silva, que, apesar de filiado ao PSD local, manteve-se afastado e buscou governar de maneira "imparcial". Neste tempo já existia uma cisão dentro do PSD local originada após a indicação de Barbosa Lima Sobrinho pela ala liderada por Agamenon Magalhães e Etelvino Lins como candidato do partido para o Governo do estado. Esses embates culminariam com a expulsão de Novais Filho, líder do grupo dos banguezeiros e fornecedores de cana que havia sido abrigado no PSD e agora estava à frente do grupo dissidente que pouco tempo depois ingressaria na UDN.

Os correligionários de Agamenon em Pernambuco continuaram a fazer oposição e críticas ao governo de Dutra, o qual terminou optando pela substituição do interventor local, nomeando o General Demerval Peixoto para o cargo. No decorrer da gestão de Peixoto, seria verificado que o Presidente não tinha cedido em nada aos pessedistas, mas sim reforçado o cerco contra o grupo de Agamenon. O General recém-ingresso no comando da $7^{\text {a }}$ Região passou a intervir em diversos municípios onde o PSD era muito forte, como também nomeou para compor seu secretariado alguns udenistas. Segundo Dulce Pandolfi, todo esse jogo fazia parte da política de conciliação com os elementos udenistas, empreendida pelo Presidente Dutra em combate resquícios do poder de Vargas e seus aliados. ${ }^{544}$

Esta situação de instabilidade política em Pernambuco só começou a tomar novos rumos após as eleições de 19 de janeiro de 1947, quando o PSD conseguiu selar sua hegemonia na política estadual, ao ser o partido com maior número de votos nos pleitos para governador do estado e para deputados estaduais. No entanto, as coisas não procederam tão calmamente como aparenta ter sido, tendo em vista que o governador Barbosa Lima Sobrinho só fora diplomado no cargo em princípios de 1948, após uma longa batalha judicial imposta pela UDN que perdurou todo o ano de 1947. Sendo assim, apesar dos entraves impostos pelos seus opositores, o PSD conseguiu se impor durante o processo de transição democrática, utilizando para isso a sua força política e depois disso apenas administrou sua hegemonia dentro da política pernambucana, a qual se estendeu durante parte considerável do período democrático.

${ }^{544}$ PANDOLFI, Op. cit., p. 120. 


\section{REFERÊNCIAS BIBLIOGRÁFICAS}

BENEVIDES, Maria Victoria Mesquita. A União Democrática Nacional: um partido em questão. São Paulo: Cadernos Cedec, 1978. v. 1.

BERTONHA, João Fábio. Os integralistas pós-1945: A busca pelo poder no regime democrático e na ditadura militar (1945-1985). In: Diálogos. Maringá, v. 13, nº 1, 2009.

CALIL, Gilberto Grassi. O integralismo no pós-guerra: a formação do PRP, 1945-1950. Porto Alegre: EDIPURS, 2001.

CHILCOTE, Ronald H. PCB: Conflito e integração. São Paulo: Edições Graal, 1982.

COELHO, Sandro Anselmo. O Partido Democrata Cristão: teores programáticos da terceira via brasileira (1945-1964). In: Revista Brasileira de História. São Paulo, v.23, nº 46, 2003.

D'ARAUJO, Maria Celina. Sindicatos, carismas e poder. O PTB de 1945-65. Rio de Janeiro: Editora FGV, 1996.

DELGADO, Lucilia de Almeida Neves. "Partidos políticos e frentes parlamentares: projetos, desafios e conflitos na democracia". In: DELGADO, Lucilia de Almeida Neves; Ferreira, Jorge (Org.). O Brasil Republicano: O tempo da experiência democrática. Rio de Janeiro: Civilização Brasileira, 2003, v. 3.

FERREIRA, Jorge. O Imaginário Trabalhista: getulismo, PTB e cultura política popular 1945 - 1964. Rio de Janeiro: Civilização Brasileira, 2005.

FERREIRA, Jorge. Prisioneiros do mito: Cultura e imaginário político dos comunistas no Brasil (19301956). Rio de Janeiro/Niterói: Mauad/Eduff, 2002. v. 1.

HIPOLLITO, Lúcia. De raposas e reformistas: O PSD e a experiência democrática brasileira, 1945-64. Rio de Janeiro: Paz e Terra, 1985.

LAVAREDA, José Antônio. Partidos no pós-guerra: primeiras eleições em Pernambuco, 1945-1947. Recife: Ed. Universitária da UFPE, 2008.

MACEDO, Michelle. O movimento queremista e a democratização de 1945: Trabalhadores na luta por direitos. Rio de Janeiro: 7Letras, 2013.

PANDOLFI, Dulce. Camaradas e Companheiros: História e Memória do PCB. Rio de Janeiro: RelumeDumará: Fundação Roberto Marinho, 1995.

PANDOLFI, Dulce. Pernambuco de Agamenon Magalhães. Recife: Massangana, 1984.

SILVA, Hélio. 1945: Porque Depuseram Vargas. ( O Ciclo de Vargas - Vol. XV) com a colaboração de Maria Cecília Ribas Carneiro. Edição Ilustrada. Rio de Janeiro, Civilização Brasileira, 1976. 